Вісник Харківського національного університету імені В.Н. Каразіна Серія "Математика, прикладна математика і механіка" Том 91,2020 , с. $21-35$

УДК 534.23, 519.6
Visnyk of V.N.Karazin Kharkiv National University Ser. "Mathematics, Applied Mathematics and Mechanics"

Vol. 91, 2020, p. 21-35

DOI: $10.26565 / 2221-5646-2020-91-02$

\title{
BVI-noise generation by wing-shaped helicopter blade
}

\author{
P. V. Lukianov \\ Institute of Hydromechanics NAS of Ukraine, \\ Kyiv, Zhelyabova 8/4, 03680, Ukraine \\ petr_lukianov@bigmir.net
}

In this work, the problem of generation BVI-noise by wing-shaped rotor blade of a helicopter is posed and solved. Research completed for near and far sound fields. In particular, it was discovered dependence of the distribution of density pulsations on the longitudinal blade geometry, angle of attack and blade angle to counter flow. Air flux speed increase promotes the generation of transverse pulsations on the surface blade that dominate longitudinal pulsations in level. The level of generated noise is in the range of $50 \mathrm{~dB} \leq L \leq 60 \mathrm{~dB}$, which is 5-6 dB lower than the noise of the Blue Edge blades, and also rounded blade at its end.

Keywords: sound generation; wing-shaped helicopter blade; BVI-noise.

Лук'янов П.В. Генерація ВVI-шуму крилоподібною лопаттю гелікоптера. В роботі поставлено та розв'язано задачу генерації BVI-шуму криловидною лопаттю ротора гелікоптера. Вивчена поведінка ближньго та дальнього звукових полів. Зокрема, виявлено залежність розподілу пульсацій густини від повздожньої геометрії лопаті, кута атаки та кута постановки лопаті до зустрічного потоку. Збільшення швидкості потоку, що набігає, сприяє зародженню поперечних пульсацій на поверхні лопаті, котрі за рівнем домінують над повздовжними пульсаціями. Рівень шуму, що генерується, знаходиться у диапазоні 50 Дб $\leq L \leq 60$ Дб, що нижче на 5-6 Дб рівня Blue Edge лопаті, а також закругленої лопаті.

Ключові слова: генерація звуку; криловидна лопать гелікоптера; BVI-шум.

Лукьянов П.В. BVI-шум крыловидной лопасти ротора вертолёта. В работе поставлена и решена задача генерации BVI-шума крыловидной лопастью ротора вертолёта. Изучено поведение ближнего и дальнего звуковых полей. В частности, обнаружена зависимость распределения пульсаций плотности от продольной геометрии лопасти, угла атаки и угла постановки лопасти к встречному потоку. Увеличение скорости набегающего потока способствует зарождению поперечных пульсаций на поверхности лопасти, которые по уровню доминируют над продольными пульсациями. Уровень генерируемого шума находится в диапазоне 50 Дб $\leq L \leq 60$ Дб, что ниже на 5-6 Дб шума Blue Edge лопасти, а также закруглённой на конце лопасти.

Ключевые слова: генерация звука; крылообразная лопасть вертолёта; BVI-шум.

2010 Mathematics Subject Classification: 76Q05; 76G25.

(C) Lukianov P. V., 2020 


\section{Introduction}

Current requirements of ICAO standards force us to search for new modifications of the rotor blade of the helicopter, which would allow reduce BVI noise. This type of noise is most expressed at moderate and low flight speeds (maneuvers) and dominates other noise of aerodynamic origin. As established in early studies, the vortex noise has a quadrupole character and substantially depends on the longitudinal geometry of the blade, the angle attack and the angle of the blade to the oncoming stream.

In earlier studies [1], [2], the main emphasis in modeling low noisy blades was given to variations in the shape of the end of the blade, starting from $z=0.8 R$, which made it possible to reduce the vortex noise for a number of blade tips. The end part of the blade is responsible for the formation of the attached vortex. Therefore, its variation allows, to one degree or another, to influence the interaction of this vortex with the blade, generating of BVI noise. However, the shape of the rest of the non-terminal part of the blade can also influence the process of the formation of vortex noise in general. Recently, a lot of attention has been paid to the study of this issue in the company "Eurocopter" - the world leader in helicopter manufacturing [3], [4]. The same research also involved in "Airbas". The noise of the blades of a modified shape along the span has been studied for today. The blade has up to the middle a straight shape, and then it is bent twice, more - closer to the outer end. The second modification of the blade is sin-shaped blade [5]. The noise of the sin-shaped rotor was 3-5 dB lower than that of the rectangular-shaped rotor. The third blade shape modification represents a wing of the bird that is not fully spread, that is, in its incomplete scope. This form of the blade is called wing-shaped blade. In particular, it was noted [3], [6] that the double swept blade is quieter by $6 \mathrm{~dB}$ than the blade without bending, has improved flight qualities.

Research in this direction is new, with a certain commercial interest, and in connection with this, the mathematical statements of the problems are not given in these works: all publications are limited only to indicating software packages developed earlier in well-known research centers ONERA, DLR, external demonstration of the shape of the blade.

In the present work, the problem of modeling noise with a wing-shaped type blade has been posed and solved. The blade has two expressed bends along its span, which give it the shape of an incompletely spread bird wing, that is, a pterygoid. The problem is solved in a three-dimensional non-stationary formulation. A comparative analysis of the results of numerical calculation of the near and far sound fields for a given blade and the calculated data for a rounded blade without double bending is presented. The comparison of the generated noise level of the pterygoid (wing shaped) blade with the blade rounded at the end, as well as the noise level data for Blue Edge blades are presented in [3]. 


\section{Problem setting}

Suppose we have a rigid double-swept blade along span, Fig.1, resembling the shape of an incompletely straightened bird wing. The distance from the butt to the outer end the blade remains equal to the length $R$ of the unbent blade. If pass along the curve of the bend of the blade, then the length of the curved blade along this curve will exceed $R$.

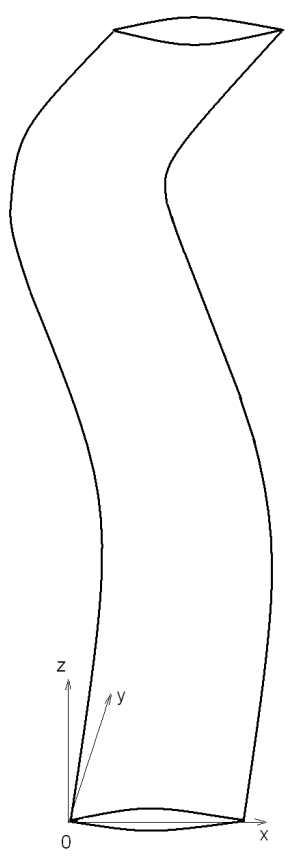

Fig.1: Double-bent wing-shaped blade.

For the mathematical formulation of the problem, we use a rectangular Cartesian coordinate system Oxyz. Moreover, we assume that on the front edge of the blade runs a swirling stream with Taylor distribution:

$$
V_{\theta}=V_{\theta \max } \frac{r}{r_{c}} \exp ^{1-\left(r / r_{c}\right)^{2}},
$$

and at the outer, with respect to the axis of rotation, end of the blade, the attached Scully vortex is induced:

$$
V_{\theta}=1.2 \cdot U_{\infty} \frac{\bar{r}_{c}}{1+\bar{r}_{c}^{2}}, \bar{r}=\frac{r}{r_{c}},
$$

where $r, \theta, r_{c}$ is the radial coordinate, azimuthal the coordinate and radius of the vortex core, respectively. Values $V_{\theta \max }, U_{\infty}$ vary along the blade. The blade in the plane of rotation is rotated by an angle $\alpha$ relative to the direction of its 
scope, and set at an angle of attack $\gamma$ to the oncoming stream. Thus, the overall picture of the flow similar to the situation for a rectangular blade [7].

The whole problem is divided into aerodynamic and acoustic parts. The aerodynamic problem is a system of equations, simulating an ideal compressible flow around the blade. In dimensionless form it will be written [8]:

$$
\begin{aligned}
\frac{\partial u^{\prime}}{\partial \tau}+u^{\prime} \frac{\partial u^{\prime}}{\partial \xi}+\lambda c v^{\prime} \frac{\partial u^{\prime}}{\partial \eta} & +\frac{c}{R} w^{\prime} \frac{\partial u^{\prime}}{\partial \zeta}= \\
& =-\frac{1}{M^{2} \rho^{\prime}} \frac{\partial \rho^{\prime}}{\partial \xi} \\
\frac{\partial v^{\prime}}{\partial \tau}+u^{\prime} \frac{\partial v^{\prime}}{\partial \xi}+\lambda c v^{\prime} \frac{\partial v^{\prime}}{\partial \eta} & +\frac{1}{A R} w^{\prime} \frac{\partial v^{\prime}}{\partial \zeta}= \\
& =-\frac{\lambda c}{M^{2} \rho^{\prime}} \frac{\partial \rho^{\prime}}{\partial \eta} \\
\frac{\partial w^{\prime}}{\partial \tau}+u^{\prime} \frac{\partial w^{\prime}}{\partial \xi}+\lambda c v^{\prime} \frac{\partial w^{\prime}}{\partial \eta} & +\frac{1}{A R} w^{\prime} \frac{\partial w^{\prime}}{\partial \zeta}= \\
= & -\frac{1}{A R M^{2} \rho^{\prime}} \frac{\partial \rho^{\prime}}{\partial \zeta},
\end{aligned}
$$

where $A R=R / c$ is the "aspect ratio", that is the ratio of blade span and lenth chords of s cross section, and

$$
\frac{\partial \rho^{\prime}}{\partial \tau}+\frac{\partial\left(\rho^{\prime} u^{\prime}\right)}{\partial \xi}+\lambda c \frac{\partial\left(\rho^{\prime} v^{\prime}\right)}{\partial \eta}+\frac{1}{A R} \frac{\partial\left(\rho^{\prime} w^{\prime}\right)}{\partial \zeta}=0 .
$$

where

$$
\begin{gathered}
u^{\prime}=\frac{u}{U_{\infty}}, v^{\prime}=\frac{v}{U_{\infty}}, w^{\prime}=\frac{w}{U_{\infty}}, p^{\prime}=\frac{p}{\rho_{\infty} U_{\infty}^{2}}, \\
\rho^{\prime}=\frac{\rho}{\rho_{\infty}}, \xi=\frac{x}{c}, \eta=\lambda y, \quad \zeta=\frac{z}{R}, \tau=k t .
\end{gathered}
$$

The first three equations (3)-(5) are the equations of motion in the form of Euler, and (6) is the continuity equation. Here $c, R, \lambda, k$ is the length chords of the blade, radius of the blade, thickness parameter, time parameter, respectively, $M$ is the Mach number, $A R=R / c$ is "aspect ratio". The oncoming stream runs at the blade at a speed $U_{\infty}$. Since the blade is rigid, then on its surface $\mathrm{S}$ normal velocity vector is zero:

$$
\left.\bar{v}_{n}\right|_{S}=\overline{0} .
$$

Equations (3)-(7), together with the distributions of the Taylor and Skully vortices (1), (2), form an aerodynamic problem. 
The acoustics problem is based on the following system of two equations [9], [10]:

$$
\begin{gathered}
\frac{\partial^{2} \bar{\rho}^{\prime}}{\partial t^{2}}-a^{2} \nabla^{2} \bar{\rho}^{\prime}=\operatorname{div}[\rho(\nabla \mathbf{v} \cdot \nabla \bar{\varphi}+(\nabla \times \mathbf{v}) \times \\
\left.\times \nabla \varphi+\mathbf{v} \cdot \nabla \bar{\varphi})+\bar{\rho}^{\prime}\left(\nabla \frac{\mathbf{v}^{2}}{2}+(\nabla \times \mathbf{v}) \times \mathbf{v}\right)\right] \\
+\operatorname{div}\left(\mathbf{v} \cdot \operatorname{div}\left(\rho \nabla \bar{\varphi}+\bar{\rho}^{\prime} \mathbf{v}\right)\right)-\operatorname{div}\left(\bar{\rho}^{\prime} \mathbf{F}\right)+ \\
+\operatorname{div}(\nabla \bar{\varphi} \cdot \operatorname{div} \rho \mathbf{v})+\nabla a^{2} \cdot \nabla \bar{\rho}^{\prime} \\
\frac{\partial \bar{\rho}^{\prime}}{\partial t}+\rho \nabla^{2} \bar{\varphi}+\nabla \bar{\varphi} \cdot \nabla \rho+\bar{\rho}^{\prime} \operatorname{div} \mathbf{v}+\mathbf{v} \cdot \nabla \bar{\rho}^{\prime}=0
\end{gathered}
$$

The first equation (8), in terms of density pulsation in sound wave, is an equation describing the generation of sound and its propagation. Equation (9) of the system is obtained from the continuity equation and closes the system with respect to two acoustic unknowns $\bar{\rho}^{\prime}, \bar{\varphi}$. We consider that before the interaction of the blade with the flow and vortices, small pulsations of the flow are absent, i.e. $\left.\bar{\rho}^{\prime}\right|_{t=0}=0,\left.\bar{\varphi}\right|_{t=0}=0$.

\section{Method of problem solving}

Since the above problem is similar to the problem for the blade without bending, then for it was taken as a basis a program using numerically-analytical method [11], [12]. This program has been modified taking into account variations in the geometry of the problem being solved. The change in the shape of the blade made the grid slightly thicker in the cross section of the blade: here on the dimensionless coordinate 85 points were set along the chord, and for a blade without double bend, recall, there were 80 of them. An increase in the number of points along the span of the blade was not necessery.

\section{Near field}

To determine the effect of double bending on the generation of BVI noise consider a wing-shaped blade along the span, section which $y=x(1-x)$ and the relative thickness $\delta=0.1$. Since this modification of the shape of the blade, it is assumed will have a certain effect on the BVI noise, then we choose the Mach number $M=0.2 ; 0.4$. For large Mach numbers $(M>0.4)$ the noise is not is predominantly vortex-type noise. Choose the following the angles of setting the blade to the oncoming flow $\alpha$ and angles of attack $\gamma: \alpha=60^{\circ}, 90^{\circ}$ and $\gamma=5^{\circ}, \gamma=10^{\circ}$.

Figure 2a, $M=0.2, \gamma=5^{\circ}, \alpha=60^{\circ}$, shows the dimensionless pulsations of the density $\bar{\rho}^{\prime}$, characteristic the feature of which is the presence of two clearly defined smooth peaks in front of the blade. These peaks prevail over the rest of the ripple field $\bar{\rho}^{\prime}$. Their shape is associated with the shape of the envelope of the leading edge of the blade. Therefore they were not present for a rectangular 
blade with a rounding at the end [13]. It should be noted that in some areas of the blade sharp local peaks appear, which indicates the existence of clearly defined zones of flow instability. All the above disturbance zones $\bar{\rho}^{\prime}$ indicate intense sound in these areas of the blade. Behind the first two smooth peaks, a whole ridge of waves "crests" is observed. Its "crests" are 2-3 times lower than the first main highs. Behind the second series of peaks, closer to the center of the blade, several consecutive wave crests are observed that are lower the second of these longitudinal series of peaks. Thus, we have three series of longitudinal perturbations decreasing in amplitude and, in addition to of this, two locally expressed transverse, at $z=0,0.5 R$, zones instability. For the angle $\alpha=90^{\circ}$, Fig.2b, the wave picture not substantially changed on the leading edge of the blade. However, noticeable slight decrease in the level of the 2nd and 3rd series of peaks, as well as significant attenuation of transverse perturbations at $z=0,0.5 R$.

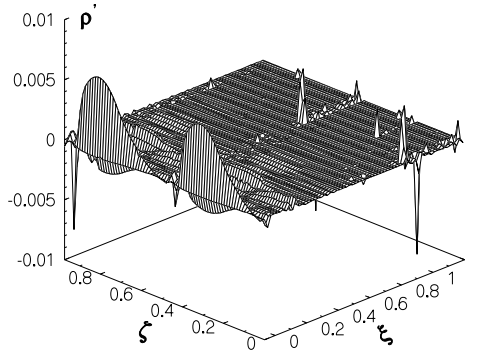

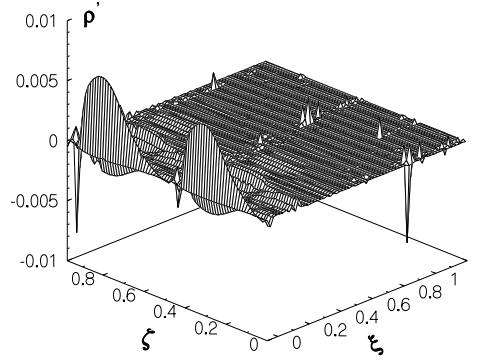

Fig.2: Dimensionless acoustical density, $\left.M=0.2, \gamma=5^{\circ}: a\right) \alpha=60^{\circ}$, b) $\alpha=90^{\circ}$.

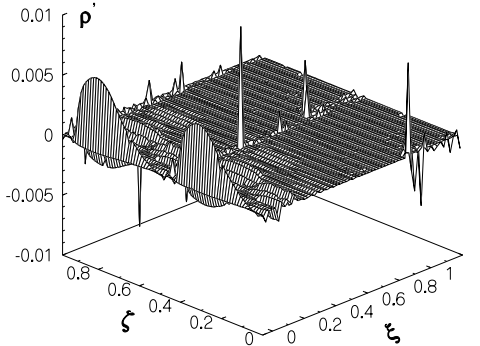

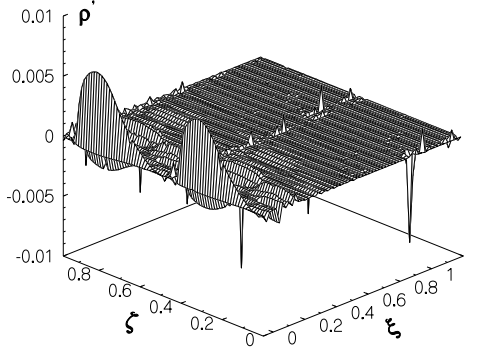

Fig.3: Dimensionless acoustical density, $\left.\left.M=0.2, \gamma=10^{\circ}: a\right) \alpha=60^{\circ}, b\right) \alpha=90^{\circ}$.

With an increase in the angle of attack $\gamma=10^{\circ}$, Fig.3a, two smooth peaks of the 1st series are practically unchanged, and the series following it ridges of a smaller size are no longer as smooth as in case $\gamma=5^{\circ}$, which indicates the origin of zones instability. Indeed, we see three transverse zones instabilities, at 
$z=0,0.5 R, R$, with locally expressed bursts. For $\alpha=90^{\circ}$, Fig. $3 \mathrm{~b}$, these local disturbances fade out and the picture as a whole resembles the case $\gamma=5^{\circ}$, $\alpha=90^{\circ}$ with only a few slight differences.

An increase in the Mach number $M=0.4$, Fig.4-5, led to a sharp activation of transverse perturbations $\bar{\rho}^{\prime}$, Fig.5a: they are in 1.5-3 times superior in amplitude to the maximum longitudinal disturbances. For the angle $\alpha=90^{\circ}$, Fig.5b, the situation is next: there are two local transverse bursts disturbances, however the remaining smaller bursts are already less expressed. Thus, if the blade is not located perpendicular to the oncoming flow, $\alpha=90^{\circ}$, and under some angle, for example $\alpha=60^{\circ}$, then the transverse disturbances are realized of a larger magnitude. Increased angle of attack also contributes, Fig.5, to the formation of zones of transverse disturbances $\bar{\rho}^{\prime}$. This is especially expressed in Fig.5a: a number of local bursts, the maximum of which is located in the center of the blade, $\xi=0.5$, clearly shows two series of transverse perturbations of $\bar{\rho}^{\prime}$. These perturbations for the case $\alpha=90^{\circ}$, Fig.5b, as already set above, fade out.
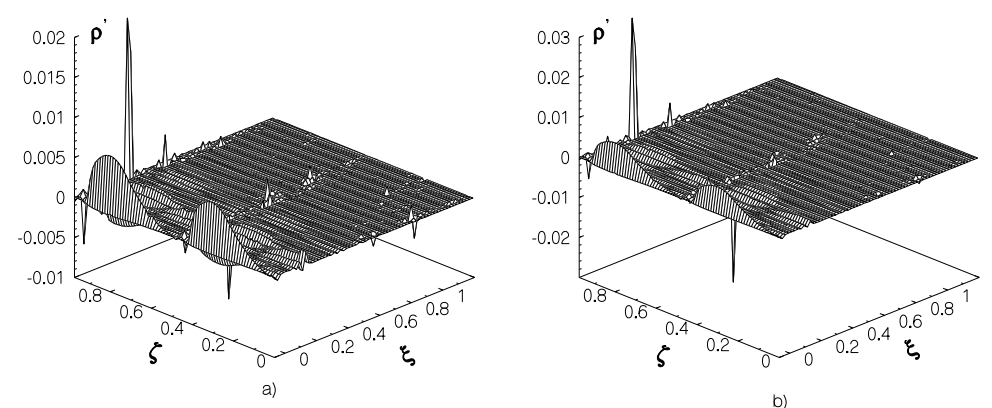

Fig.4: Dimensionless acoustical density, $\left.\left.M=0.4, \gamma=5^{\circ}: a\right) \alpha=60^{\circ}, b\right) \alpha=90^{\circ}$.
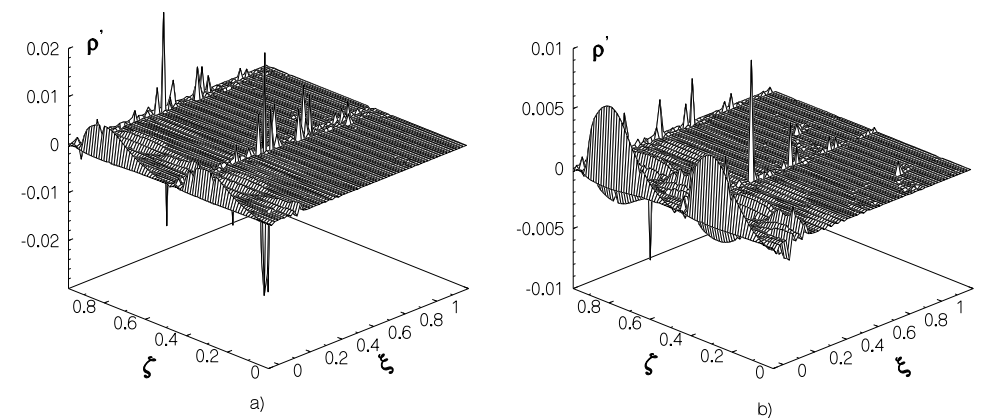

Fig.5: Dimensionless acoustical density, $M=0.4, \gamma=10^{\circ}$ : a) $\left.\alpha=60^{\circ}, b\right) \alpha=90^{\circ}$. 


\section{Far field}

To study the behavior of generated far-field noise we use the integral representation of the far field [8], [10]:

$$
\begin{array}{r}
\int_{S}\left[\frac{1}{R} \frac{\partial \phi^{\prime}}{\partial n}+\frac{1}{R a_{\infty}} \frac{\partial R}{\partial n} \frac{\partial \phi^{\prime}}{\partial t}-\phi^{\prime} \frac{\partial(1 / R)}{\partial n}\right]_{t^{*}} d S- \\
-M_{1}^{2} \int_{S}\left[\frac{F}{R}\right]_{t^{*}} d S=4 \pi \phi^{\prime}\left(x, t_{1}\right),
\end{array}
$$

where

$$
\begin{array}{r}
F=\rho[(\nabla \phi \cdot \nabla) \bar{v}+(\bar{v} \cdot \nabla) \cdot \nabla \phi]+\rho^{\prime}(\bar{v} \cdot \nabla) \bar{v}+ \\
+\bar{v} \cdot \operatorname{div}\left(\rho \nabla \phi+\rho^{\prime} \bar{v}\right)+\nabla \phi \operatorname{div}(\rho \bar{v}) .
\end{array}
$$

However, the directly numerical values of $\phi$ are not interesting. The sound pressure level $L$ is important, which is calculated from the received data of $\phi$, its derivatives. It should be recalled that the integral representation of the far field 10 includes only those sound sources that contribute to the integral over a considerable distance from the surface of the blade, that is, in the far field. Secondly, this representation is derived from Kirchhoff's famous approach, the essence of which is that sound potential at a given fixed point integrally depends on the distribution of sound sources throughout the blade. In fact, it does not reflect a local disturbance, but the interference sound in general. Therefore, the graphs of sound pressure level $L$, which are given below, are not separate local perturbations, but nonlinear sound wave. Below are the graphs of sound pressure level $L$ and their analysis.

Changing the shape of the blade along its wingspan in the form of a wing allowed distribute the energy of the generated sound wave more evenly throughout the entire blade, Fig.6a. In addition, it can be seen that along the span of the blade, the sound wave has a nonlinear shape with alternating maximums and
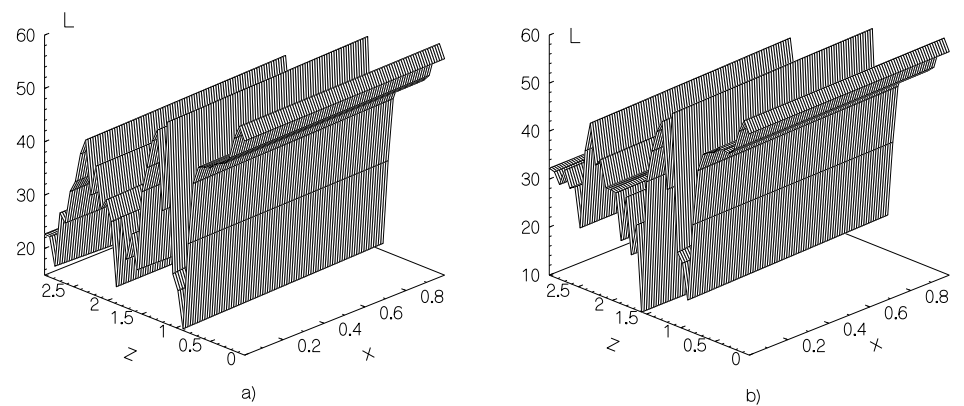

Fig.6: Standard pressure level, $\left.M=0.2, \gamma=5^{\circ}: a\right) \alpha=60^{\circ}$, b) $\alpha=90^{\circ}$. 
minimums of $L$. The maximum value of $L$ does not exceed $60 \mathrm{~dB}$ and is located not on the outer, with respect to the axis of rotation, end of the blade, but its central part. On the outside at the end of the blade there is a lower value of $L$. The same situation is also observed for $\alpha=90^{\circ}$, Fig.6b, so the only difference is that for $0.5 R \leq z \leq R$ the level of $L$ is somewhat higher, and the maximum-minimum difference decreases.

For the angle of attack $\gamma=10^{\circ}$, Fig.7a, the maximum of $L$ at the end of the blade is close to the other two maxima, that is, a significant decrease in $L$ at the end of the blade is not achieved. However, the overall picture of the distribution of the noise level is such that $50 \mathrm{~dB} \leq L \leq 60 \mathrm{~dB}$. This suggests that the wingshaped blade is not noisy. Less noisy is the part of the blade in the region of $z=0.3 R$. For $\alpha=90^{\circ}$, Fig.7b, the maximum of the noise level is lower by about $5 \mathrm{~dB}$ than for the case $\alpha=60^{\circ}$, in the region of the outer end of the blade. Note that for the angle of attack $\gamma=5^{\circ}$ the blade with a rounded edge generates noise at about the same level as the wing-shaped blade. And for the angle of attack $\gamma=10^{\circ}$ the noise level of a blade rounded at the end higher, about $66-67 \mathrm{~dB}$, than the wing-shaped blade.

For the Mach number $M=0.4, \gamma=5^{\circ}$, Fig.8, the noise level reaches values of $80 \mathrm{~dB}$ in the region of $z=0.7 R-0.8 R$, which indicates the dominance of rotation noise over vortex noise. According to Gutin [14] the maximum rotation noise should be located in this area. In the rest of the blade, closer to its ends, the behavior of $L$ is similar to the case of $M=0.2$. For the angle of attack $\gamma=10^{\circ}$, Fig.9a, the pressure wave has a locally expressed maximum in the region of $z=0.8 R$ to $80 \mathrm{~dB}$, which gradually decreases, to the butt, to $60 \mathrm{~dB}$. The prevalence of rotational noise is clearly visible here. The same situation was observed for the blade with a rounding at the end. At the same time, for the angle $\alpha=90^{\circ}$, Fig.9b, the vortex nature of noise reappears: the noise level is not exceeding $60 \mathrm{~dB}$, more smoothly distributed along the blade than in case $M=0.2$. It is noteworthy that for a fixed value of the coordinate $z$ along the span of the blade the pressure level in the sound wave varies within $2 \mathrm{~dB}$. However, on the $L$ charts due to the significant difference in $L$ this is practically not noticeable. In absolute terms, not in $\mathrm{dB}$, this difference means a tangible, tens of percent, variation sound potential.

Let us compare the obtained pressure level data with the available data [3] for the Blue Edge blades. Recall that the Blue Edge blade generates noise in the range of $50 \mathrm{~dB} \leq L \leq 65 \mathrm{~dB}$. The wing-shaped blade considered in this work for most design situations showed a noise level of no higher than $60 \mathrm{~dB}$. Only in certain design situations rotation noise exceeds vortex noise.

As for the spectrum of the generated noise, it should be noted following features. The envelope in the noise spectrum is more broken for lower values of Mach numbers, $M=0.2$, and smaller angles of attack, $\gamma=5^{\circ}$. For $M=0.4$, $\gamma=10^{\circ}$ envelope smoother. The envelope shape clearly shows the zones greatest sound generation along the blade. Also, judging by the level individual harmonics, it can be seen that the main noise energy in the frequency the spectrum is 

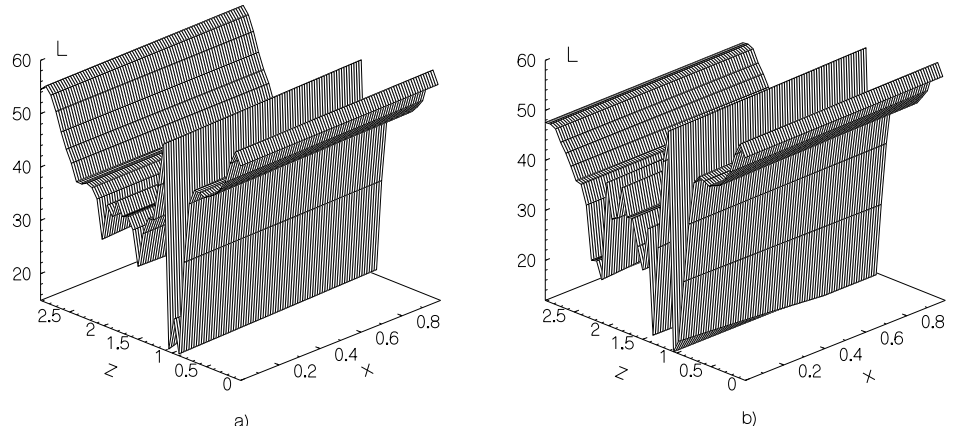

Fig.7: Standard pressure level, $\left.\left.M=0.2, \gamma=10^{\circ}: a\right) \alpha=60^{\circ}, b\right) \alpha=90^{\circ}$.
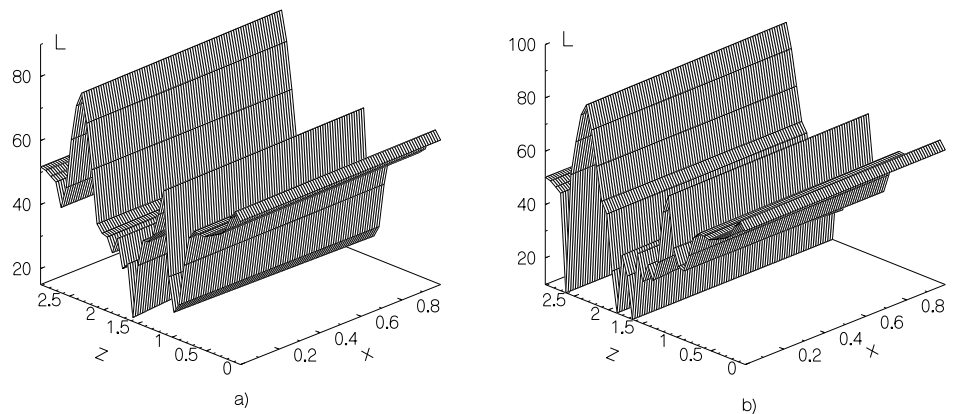

Fig.8: Standard pressure level, $\left.\left.M=0.4, \gamma=5^{\circ}: a\right) \alpha=60^{\circ}, b\right) \alpha=90^{\circ}$.
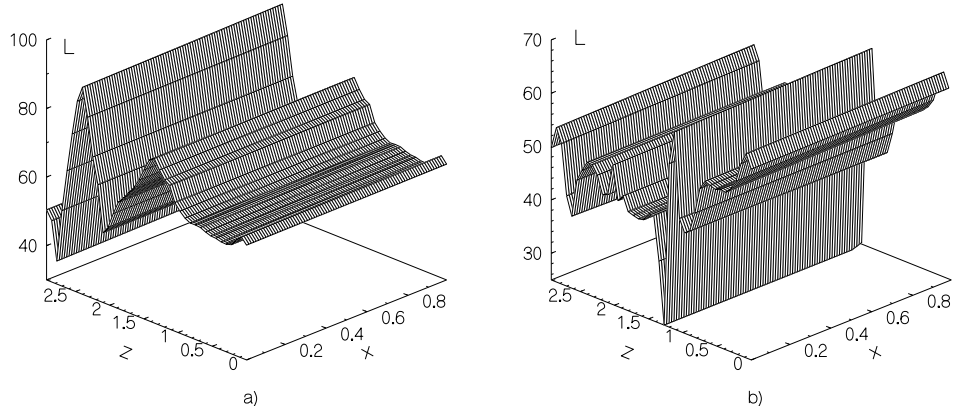

Fig.9: Standard pressure level, $M=0.4, \gamma=10^{\circ}$ : a) $\left.\alpha=60^{\circ}, b\right) \alpha=90^{\circ}$. 

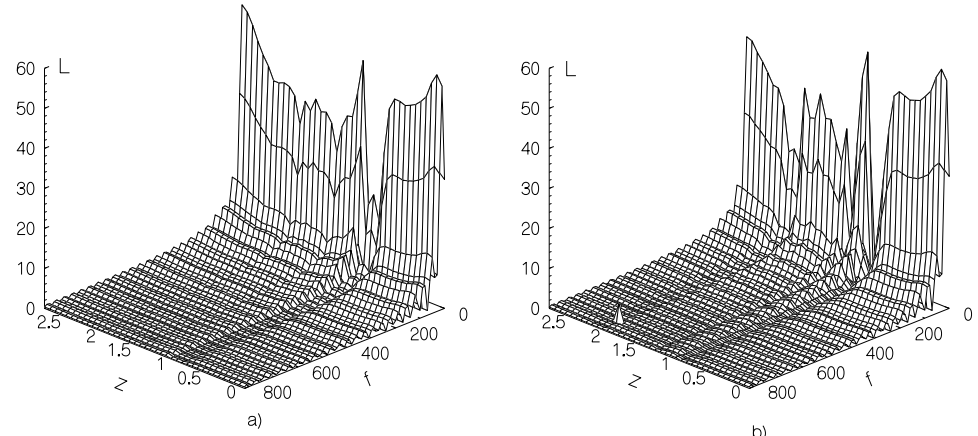

Fig.10: Spectral pressure level (dB), $M=0.2, \gamma=10^{\circ}$ : a) $\left.\alpha=60^{\circ}, b\right) \alpha=90^{\circ}$.
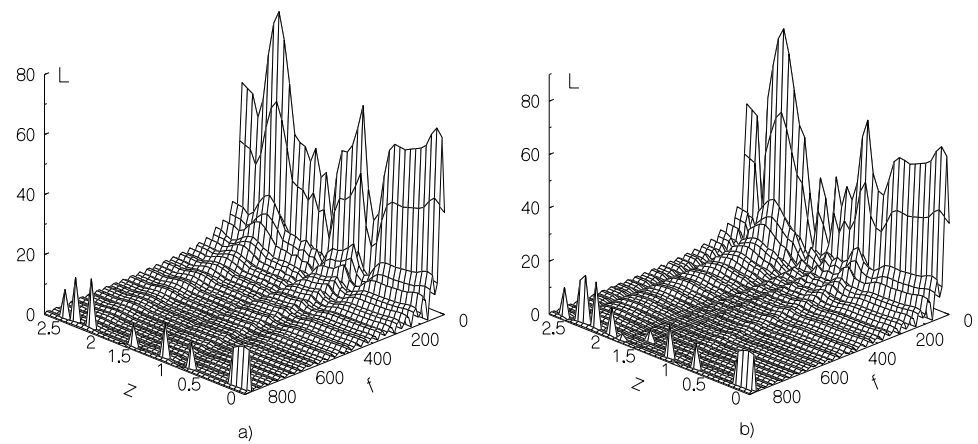

Fig.11: Spectralp pressure level (dB), $\left.\left.M=0.4, \gamma=5^{\circ}: a\right) \alpha=60^{\circ}, b\right) \alpha=90^{\circ}$.
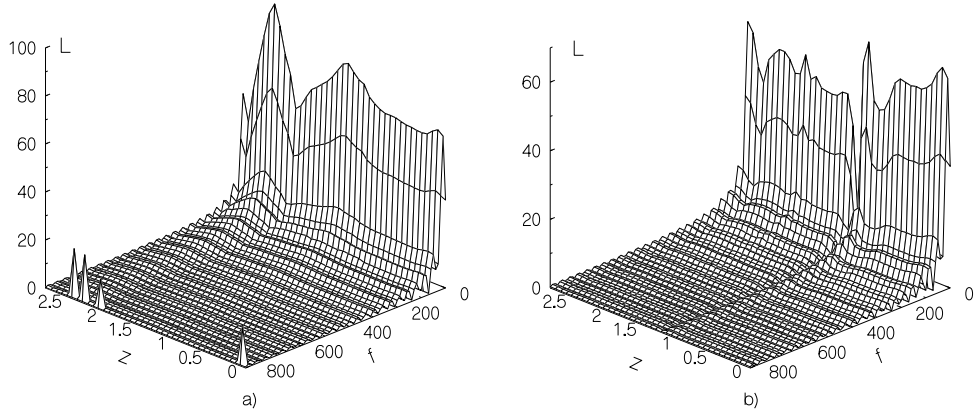

Fig.12: Spectral pressure level (dB), $\left.\left.M=0.4, \gamma=10^{\circ}: a\right) \alpha=60^{\circ}, b\right) \alpha=90^{\circ}$. 
concentrated in the first 5-7 harmonics, Fig.10-12. The angle of attack $\gamma=5^{\circ}$ is characterized by the appearance high-frequency harmonics, $f \approx 840 \mathrm{~Hz}$, in the spectrum. Note that a similar situation has already been observed for the rectangular blade [15], but there the frequency was close to $f \approx 700 \mathrm{~Hz}$. Estimated in the work data are consistent with currently known estimates and experimental results: BVI noise is in the range close to $60 \mathrm{~dB}$ [3], and the rotation noise above it by $15-20 \mathrm{~dB}$, i.e. varies in the range of $80 \mathrm{~dB}[16]$.

\section{Conclusions}

1.The problem of generating BVI noise is posed and numerically solved for double-bent wing-shaped blade, interacting with swirl flow.

2. The near field calculated data found the following interesting features. In the near sound field a longitudinal series of two smoothly distributed peaks is clearly visible, displaying the longitudinal bend geometry of the blade that are not previously observed for a rectangular blade. These peaks are present in all considered numerical situations. For this a series of two more longitudinal series of smooth peaks are observed. Each of these series of peaks is 1.5-3 times smaller in amplitude of the previous series. In addition to the longitudinal series of acoustic density disturbances the appearance of 2-3 transverse series of locally expressed peaks is fixed. These series dominate in amplitude with increasing Mach number and angle of attack of the blade.

3. The results of the calculation of the far field showed that the blade wingshaped generates BVI noise in the region of $60 \mathrm{~dB}$, which is 5- $6 \mathrm{~dB}$ lower noise Blue Edge blade. This suggests that the wing-shaped blade can consider low noise: only in certain settlement situations it turned out that the generated noise is rotation noise, with elevated level, on a certain part of the blade.

4.The obtained calculation results are consistent with the available calculated and experimental data of other authors.

ORCID ID

P. V.Lukianov (iD https://orcid.org/0000-0002-7584-1491

\section{REFERENCES}

1. Robert M. Kufeld, Jeffrey L. Cross, William G. Bousman. A survey of Rotor Loads Distribution in Maneuvering Flight, American Helicopter Society Aeromechanics Specialists Conference, San Francisco, CA, - 1994. - January 19-21. - P. 2.4-1-2.4-15.

2. Brian D. Roth. Acoustic source and data acquisition system for a helicopter rotor blade-vortex Interaction (BVI) noise reduction experiment, Thesis, December, Monterey, California, - 1996. - P. 74. 
3. P. Rauch, M. Geravais, P. Cranda, A. Baud, J., F. Hirsch, A. Walter, P. Beaumier. The Design, Development and Testing of a New Blade Concept, American Helicopter Society 67th Annual Forum, Virginia Beach, VA, 2011.- May 3-5 - 14P.

4. Y. Delrieux. From design to flight testing: overview of rotocraft acoustic research at Onera for industrial application, Aerospace Lab.Journal, - 2014. - 7. - P. 1-10. DOI: $10.12762 / 2014$.AL07-02

5. P. V. Lukianov. BVI-noise simulation of two-blade helicopter's rotor sin shape, Visnyk of V. N. Karazin Kharkiv National University, Ser. Mathematics, Applied Mathematics and Mechanics, - 2019. - 89. - P. 59-75. DOI: $10.26565 / 2221-5646-2019-89-05$

6. B. S. Mattos. Overview of Rotorcraft Technology and Market. 2011, 109 p.

7. P. V. Lukianov. Influence of the helicopter's rotor blade tip bound vortex on BVI-noise generation, Bulletin of Chercassy University, Ser.: applied mathematics, informatics, - 2014. - 311, 18. - P. 46-58.

8. P. V. Lukianov. Sound generation by Taylor and Scully Vortexes and the the Blade of the Varing Cross Section, "Naukovy Visty" - Research Bulletin of National Technical University of Ukraine "Kyiv Polytechnical Institute", 2014. - 96, 4. - P. 139-145. DOI: 10.20535/1810-0546.2014.4.28305

9. P. V. Lukianov. On one model for aeroacousics of viscous compressible gas. Part I. Analysis of existing models, dedusing of resolving system of equations, Acoustic bulletin, - 2013-2014. - 16, 2. - P. 18-30.

10. P. V. Lukianov. On one model for aeroacousics of viscous compressible gas. Part I. Analysis of existing models, dedusing of resolving system of equations, Acoustic bulletin, - 2013-2014. - 16, 3. - P. 31-40.

11. P. V. Lukianov. On one numerically-analytical approach to solving of a problem on sound generation by a thin wing. Part I. General schematic of application to planer stationary problem, Acoustic bulletin, - 2011 - 14, 3. - P. 46-52.

12. P. V. Lukianov. On one numerically-analytical approach to solving of a problem on sound generation by a thin wing. Part II. A schematic of application to non-stationary problems, Acoustic bulletin, - 2012 - 15, 3. - P. 45-52.

13. P. V. Lukianov. Influence of blade tip rounding on level of BVI-noise, Acoustic bulletin, - 2015 - 17, 2. - P. 23-37.

14. L. Gutin. On sound field of rotating propeller, Journal of Technical Physics, - 1936. - 5(6). - P. 899-906. 
15. P. V. Lukianov. Sound generation by blade and vortex near interaction at oblique angle of flow streamlining, Bulletin of Kyiv National University named after T. G. Shevchenko, Ser.: phys.- math. Sciences, - 2014. - 4. - P. 81-86.

16. M. E. Goldstein. Aeroacoustics. 1981. McGrawHill Int. Company, New York, 296 p.

Лук'янов П. В. BVI-шум криловидної лопаті ротора гелікоптера. Шум аеродинамічного походження складається з ряду компонент, серед яких шум обертання та вихровий шум, BVI-noise, дають найбільший внесок у загальний рівень шуму, що генерується. Шум обертання залежить від величини швидкості потоку, що набігає на лопать, та превалює над іншими складовими шуму при значних числах Маху обтікання лопаті. На відміну від шуму обертання, вихровий шум проявляється при невеликих швидкостях польоту гелікоптеру, помірних числах Маху. У його формуванні важливу роль відіграє повздовжня геометрія лопаті. Тому у останній час форму лопаті гелікоптера вибирають близької до існуючих природних форм, які максимально збалансовані. Однією з таких форми може бути криловидна лопать - "wing-shaped blade". В даній роботі поставлено та розв'язано задачу генерації BVI-шуму криловидною лопаттю ротора гелікоптера. Математична модель задачі побудована на запропонованій раніше автором та успішно перевіреній системи рівнянь аероакустики для загального випадку. Розрахунковими функціями у даній системі є пульсації звукового тиску та звуковий потенціал. Отримані розрахункові дані цих величин, а також їх похідних, використано для дослідження ближнього та дальнього звукових полів, вивчена поведінка ближньго та дальнього звукових полів. Зокрема, виявлено залежність розподілу пульсацій густини від повздожньої геометрії лопаті, кута атаки та кута постановки лопаті до зустрічного потоку. Збільшення швидкості потоку, що набігає, сприяє зародженню поперечних пульсацій на поверхні лопаті, котрі за рівнем домінують над повздовжними пульсаціями. Цікавою особливістю, поміченою під час розрахунків, $є$ те що, що для помірних значень числа Маху $M=0.2,0.3$ існують розрахункові ситуації, при певних кутах постановки лопаті до потоку та кутах атаки, де шум обертання домінує над вихровим шумом. Для значень числа Маху $M>0.4$ шум обертання відіграє основну роль у генерації шуму лопаттю. Рівень шуму, що генерується, знаходиться у диапазоні 50 Дб $\leq L \leq 60$ Дб, що нижче на 5-6 Дб рівня Blue Edge лопаті, а також закругленої лопаті. Крім того, підмічено активізацію високочастотної області у спектрі шуму на частоті $f \approx 840$ Гц. Результати розрахунків кажуть про те, що лопать криловидної форми є малошумною у режимі маневрів при малих швидкостях польоту.

Ключові слова: генерація звуку; криловидна лопать гелікоптера; BVI-шум.

P. V. Lukianov. BVI-noise of wing-shaped helicopter's rotor blade. Aerodynamic noise includes a number of noise components, among which rotational noise and vortex noise (BVI-noise) make the largest contribution to the overall noise generated. Rotation noise depends on the magnitude of the velocity of the incoming blade and prevails over other noise components at significant Mach Mach numbers. Unlike rotation noise, vortex noise is evident at low helicopter flight speeds, moderate Mach numbers. In the formation of this type of noise, an important role is played by the longitudinal geometry. Therefore, recently the shape of the helicopter blade is chosen close to existing natural forms, which are as balanced as possible. One of these may be a wing-shaped blade. In this work, the problem of generating BVI noise by the wing shaped blade of a helicopter is posed and solved. The mathematical model of the problem is constructed on the previously 
proposed by the author and successfully tested system of aeroacoustic equations for the general case. Estimated features in this system are pulsations of sound pressure and sound potential. The calculated data of these quantities, as well as their derivatives, were used to study near and far sound fields. In particular, the dependence of the density ripple distribution is revealed from the blade geometry, the angle of attack and the blade angle to the oncoming flow. Increasing flow velocity contributes to the emergence of transverse ripples on the surface blades that dominate the longitudinal ripples by level. An interesting feature noticed in the calculations is that there are calculations for moderate Mach numbers $M=0.2,0.3$ situations, at certain angles of blade placement to the stream and angles of attack where rotation noise dominates eddy noise. For values Mach numbers $M>0.4$ rotation noise plays a major role in blade noise generation. The noise level generated is in the range $50 \mathrm{~dB} \leq L \leq 60 \mathrm{~dB}$, which is lower by $5-6 \mathrm{~dB}$ for the Blue Edge blade, as well as the rounded blade. In addition, activation of the high-frequency region in the frequency spectrum of noise was observed $f \approx 840 \mathrm{~Hz}$. The results of the calculations show that the blade of the wing-shaped is low-noise in the mode of maneuvers at small flight speeds.

Keywords: sound generation; wing-shaped helicopter blade; BVI-noise.

Article history: Received: 18 January 2020; Final form: 28 March 2020;

Accepted: 31 March 2020. 